\title{
THE INCIDENCE AND LEVEL OF LISTERIA SPP. AND LISTERIA MONOCYTOGENES CONTAMINATION IN PROCESSED POULTRY AT A POULTRY PROCESSING PLANT
}

\author{
CLÁUdiA A.C. LOURA ${ }^{1}$, ROGERIA C.C. ALMEIDA ${ }^{1}$ AND \\ PAULO F. ALMEIDA ${ }^{2,3}$ \\ ${ }^{1}$ Departamento de Ciência dos Alimentos da Escola de Nutrição \\ ${ }^{2}$ Departamento de Ciências da Biointeração do Instituto de Ciências da Saúde \\ UFBA, Av. Reitor Miguel Calmon, $s / n$. \\ Canela, CEP 40110-160 \\ Salvador, BA, Brazil
}

Accepted for Publication September 9, 2004

\begin{abstract}
To estimate the incidence and levels of Listeria spp. in an industrial poultry processing plant, samples of chicken breast meat, livers, surfaces of saws and tables, hands and gloves were analyzed. Forty percent of the breast samples presented Listeria: L. monocytogenes, L. innocua and L. grayi. Liver samples were contaminated by $\mathrm{L}$. innocua and $\mathrm{L}$. grayi. High levels of Listeria monocytogenes were found on saws $(<30-2400$ MPN/equipment) and tables $(<30-11,000$ MPN/equipment). Hands were contaminated by L. monocytogenes, L. innocua and $\mathrm{L}$. grayi and gloves with $\mathrm{L}$. innocua and $\mathrm{L}$. grayi. The levels of Listeria on hands and gloves were low ( $<110$ MPN/hand). L. monocytogenes serotypes were $1 / 2 a, 1 / 2 b, 1 / 2 c$ and $4 b$. Overall, the study demonstrated the high prevalence of Listeria spp. and specifically L. monocytogenes in chicken breast meat, equipment and hands. Improvements and innovations at the poultry processing plant may effectively reduce final production contamination with Listeria.
\end{abstract}

\section{INTRODUCTION}

Listeria monocytogenes is of major concern to the meat industry and several outbreaks of listeriosis have in recent times occurred in Europe (Salvat et al. 1995; Dorozynski 2000). The pathogen has been found regularly in poultry products and environments where meat is processed. It is capable of

\footnotetext{
3 Author for correspondence. TEL: +55-71-2352416; FAX: +55-71-2458917; EMAIL: pfa@ufba.br
} 
surviving in these environments for long periods (Salvat et al. 1995) and frequencies of $41-84 \%$ have been reported from broiler carcasses and raw chicken products (Lawrence and Gilmour 1994; Franco et al. 1995; Uyttendaele et al. 1999).

Although present in the environment and on food raw materials, one of the major sources of L. monocytogenes in food products is the processing environment itself. Listeria monocytogenes can colonize the processing environment, utensils, brines, etc. (Lawrence and Gilmour 1995; Giovannacci et al. 1999; Rorvik et al. 2000; Fonnesbech Vogel et al. 2001a,b). This colonization, as well as job rotation of staff among departments, have been identified as primary mechanisms for contamination of the final products in some processing lines. In most cases, the contamination of the final product is believed to have occurred during processing because the strains found in the incoming raw materials are different from the strains found in the final product (Autio et al. 1999; Fonnesbech Vogel et al. 2001a,b). In other cases, when the strains of L. monocytogenes contaminating the raw materials were indistinguishable from those isolated from the final product, the contaminated incoming raw materials are considered to be the source of continuing contamination (Lawrence and Gilmour 1995; Giovannacci et al. 1999; Fonnesbech Vogel et al. 2001a).

Raw broilers are cooked before consumption, but there is a risk of crosscontamination with other foodstuffs in the consumer's kitchen. Listeria monocytogenes is able to grow and form biofilms on various food-processing surfaces, enhancing survival (Miettinen et al. 2001). Improper cleaning and disinfecting of machines in poultry abattoirs may lead to contamination of the poultry carcasses.

The focus of this study was to evaluate the incidence and level of Listeria spp. and L. monocytogenes contamination at one section of broiler meat processing located in the abattoir. Furthermore, we aimed to discover where L. monocytogenes contamination occurs in the processing line of chicken breast meat. The contaminating stages need to be identified so that they can undergo special cleaning and disinfection.

\section{MATERIALS AND METHODS}

\section{Sampling Procedure}

A state inspected poultry processing plant cooperated in this study. Conventional slaughtering and processing techniques are used in this plant that processes approximately 12,000 carcasses daily. The poultry was scalded at $55 \mathrm{C}$ for $90 \mathrm{~s}$. Potable water was used in the scalding tank and feather pickers. 
Prechiller and chiller waters contained up to 100 p.p.m. chlorine. Twenty percent of the whole chicken was placed in an ice chest and transferred to the cutting room. The pieces were classified and packaged in the same room. The temperature of the processing environment ranged between 27 and $32 \mathrm{C}$ in the bleeding, scalding and defeathering areas and $12-15 \mathrm{C}$ in the evisceration, cutting and packaging rooms. The equipment and environment were cleaned at midday and at the end of the day using alkaline soap and a $34.4 \%(\mathrm{w} / \mathrm{v})$ quaternary ammonium compound.

Slaughterhouse sampling sites included: 10 samples of liver taken immediately after coming out of the giblet chiller and 10 samples of chicken breast meat taken directly from the package at the end of the processing line, 10 samples from mechanical saws, 10 samples from the stainless steel cutting table, 10 samples from bare hands and 10 samples from hands with gloves worn by the food handler.

Saws and tables were sampled by wetting sterile polyurethane sponges $(5 \times 2 \times 5 \mathrm{~cm})$ in PBS $(\mathrm{pH} 7)$ with $0.5 \%$ sodium thiosulfate and $0.1 \%$ tween to neutralize compounds used for cleaning. For the table, the sampling was performed on an area of $0.6 \times 1.0 \mathrm{~m}$ and for saws in the cutting area $(0.03 \times 0.2 \mathrm{~m})$. The sponges were placed into sterile plastic bags that contained $100 \mathrm{~mL}$ of Listeria Enrichment University of Vermont Medium (UVM). Samples of worker hands and gloves were obtained using sterile polyurethane sponges too. All samples collected at the processing plant were placed in an insulated cold box filled with ice and brought to the laboratory for analysis within $6 \mathrm{~h}$ of collection (Messer et al. 1992). Decimal dilutions from homogenate were prepared in $0.1 \%(\mathrm{w} / \mathrm{v})$ peptone water.

Polyurethane sponges were acquired in local supermarkets and tested for inhibition properties (Daley et al. 1995).

In the laboratory, portions of $25 \mathrm{~g}$ of chicken breast meat and liver were obtained in laminar flow hood, placed in an aluminum cup containing $225 \mathrm{~mL}$ of Listeria Enrichment Broth (LEB) and then homogenized using a homogenizer for $2 \mathrm{~min}$. Decimal dilutions from homogenate were prepared in $0.1 \%$ $(\mathrm{w} / \mathrm{v})$ peptone water.

\section{Isolation and Enumeration of Listeria spp.}

Counting of Listeria spp. was carried out using the Most Probable Number (MPN) technique. For this, all bags and bottles containing the samples in UVM and LEB were incubated aerobically at $30 \mathrm{C}$ for $24 \mathrm{~h}$. After this, the contents were mixed very well and a volume of $10 \mathrm{~mL}$ from the first dilution $\left(10^{-1}\right)$ of foods and second dilution $\left(10^{-2}\right)$ of equipment, hands and gloves was transferred to three sterile empty tubes and a volume of $1 \mathrm{~mL}$ of the same dilution was transferred to three other sterile tubes containing $9 \mathrm{~mL}$ of LEB 
in order to obtain the second and third dilutions, respectively. A volume of $1 \mathrm{~mL}$ from the $10^{-2}$ and $10^{-3}$ dilutions from food samples and $1 \mathrm{~mL}$ of the $10^{-3}$ and $10^{-4}$ dilutions from equipment, hands and gloves samples in peptone water was transferred to another three tubes series containing $9 \mathrm{~mL}$ of LEB, to obtain the dilutions $10^{-3}$ and $10^{-4}$ (foods) and $10^{-4}$ and $10^{-5}$ (equipment, hands and gloves). The inoculated tubes were incubated at $30 \mathrm{C}$ for $24 \mathrm{~h}$ and then an aliquot of $0.1 \mathrm{~mL}$ from each tube was transferred to other tubes containing $10 \mathrm{~mL}$ of Fraser broth and incubated at $35 \mathrm{C}$ for $48 \mathrm{~h}$. To confirm the MNP of Listeria spp. $0.01 \mathrm{~mL}$ of dark Fraser was streaked onto Modified Oxford medium (MOX). At least five typical dark esculin-positive colonies from each plate served to identify Listeria spp. using the same procedure as that used for its detection (Donnelly et al. 1992). MPN estimation was obtained from the number of tubes with Listeria confirmed (after streaking on MOX and biochemical and CAMP tests, "true" MPN) and from the number of dark Fraser broth tubes ("predictive" MPN).

Serotyping of isolates was carried out by agglutination reactions with absorbed rabbit antisera (somatic and flagellar) as described by Seeliger and Hohne (1979). The antisera were obtained from Department of Bacteriology, Oswaldo Cruz Institute, RJ.

A table was used to calculate the MPN of Listeria spp. (AOAC 1996).

All microbiological media were from Difco Laboratories, Detroit, Michigan.

\section{RESULTS AND DISCUSSION}

\section{Prevalence and Most Probable Number of Listeria spp. in Chicken Breast Meat and Chicken Liver}

The data in Tables 1 and 2 show the prevalence and the MPN/g of species of Listeria isolated from chicken breast meat and chicken liver, respectively.

A total of $40 \%$ of chicken breast samples were contaminated by $L$. monocytogenes serotype $1 / 2 \mathrm{~b}$ (Table 1 ). All nonhaemolytic isolates were identified as $L$. innocua serotype $6 \mathrm{a}$ and $L$. grayi. MPN/g of $L$. monocytogenes were found within the range $<3-9.1$ (Table 2).

Inoue et al. (2000) also isolated L. monocytogenes from $37.0 \%$ of 46 minced chicken samples in Japan and serotypes $1 / 2 \mathrm{a}$ and $1 / 2 \mathrm{~b}$ were isolated from all the food groups investigated. According to the authors, the MPN values were higher than $100 / \mathrm{g}$ in five $(10.9 \%)$ minced chicken samples. In this present work despite that the frequency of L. monocytogenes isolation has been similar to that presented by Inoue et al. (2000), the MPN value observed was lower. 
TABLE 1.

OCCURRENCE OF LISTERIA SPP. IN SAMPLES OF CHICKEN BREAST MEAT AND LIVER, SURFACES OF SAWS AND TABLE, HANDS AND GLOVES OF FOOD HANDLERS

\begin{tabular}{|c|c|c|c|c|c|c|c|}
\hline \multirow[t]{2}{*}{ Listeria species } & \multicolumn{7}{|c|}{ Samples } \\
\hline & $\begin{array}{l}\text { Breast } \\
\mathrm{P} / \mathrm{T} \\
(\%)\end{array}$ & $\begin{array}{l}\text { Liver } \\
\mathrm{P} / \mathrm{T} \\
(\%)\end{array}$ & $\begin{array}{l}\text { Saw } \\
\text { P/T } \\
(\%)\end{array}$ & $\begin{array}{l}\text { Table } \\
\mathrm{P} / \mathrm{T} \\
(\%)\end{array}$ & $\begin{array}{l}\text { Hands } \\
\mathrm{P} / \mathrm{T} \\
(\%)\end{array}$ & $\begin{array}{l}\text { Gloves } \\
\mathrm{P} / \mathrm{T} \\
(\%)\end{array}$ & $\begin{array}{l}\text { Total } \\
\mathrm{P} / \mathrm{T} \\
(\%)\end{array}$ \\
\hline Listeria spp. & $\begin{array}{l}4 / 10 \\
(40)\end{array}$ & $\begin{array}{l}3 / 10 \\
(30)\end{array}$ & $\begin{array}{l}5 / 10 \\
(50)\end{array}$ & $\begin{array}{l}10 / 10 \\
(100)\end{array}$ & $\begin{array}{l}6 / 10 \\
(60)\end{array}$ & $\begin{array}{l}2 / 10 \\
(20)\end{array}$ & $\begin{array}{l}30 / 60 \\
(50)\end{array}$ \\
\hline L. monocytogenes & $\begin{array}{l}4 / 10 \\
(40)\end{array}$ & $\begin{array}{l}0 / 10 \\
(0)\end{array}$ & $\begin{array}{l}3 / 10 \\
(30)\end{array}$ & $\begin{array}{l}8 / 10 \\
(80)\end{array}$ & $\begin{array}{l}2 / 10 \\
(20)\end{array}$ & $\begin{array}{l}0 / 10 \\
(0)\end{array}$ & $\begin{array}{l}17 / 60 \\
(28.3)\end{array}$ \\
\hline L. inпосиа & $\begin{array}{l}2 / 10 \\
(20)\end{array}$ & $\begin{array}{l}1 / 10 \\
(10)\end{array}$ & $\begin{array}{l}3 / 10 \\
(30)\end{array}$ & $\begin{array}{l}5 / 10 \\
(50)\end{array}$ & $\begin{array}{l}3 / 10 \\
(30)\end{array}$ & $\begin{array}{l}1 / 10 \\
(10)\end{array}$ & $\begin{array}{l}15 / 60 \\
(25)\end{array}$ \\
\hline L. grayi & $\begin{array}{l}1 / 10 \\
(10)\end{array}$ & $\begin{array}{l}2 / 10 \\
(20)\end{array}$ & $\begin{array}{l}5 / 10 \\
(50)\end{array}$ & $\begin{array}{l}9 / 10 \\
(90)\end{array}$ & $\begin{array}{l}4 / 10 \\
(40)\end{array}$ & $\begin{array}{l}1 / 10 \\
(10)\end{array}$ & $\begin{array}{l}23 / 60 \\
(38.3)\end{array}$ \\
\hline
\end{tabular}

P, positive samples; $\mathrm{T}$, total of samples analyzed.

Pini and Gilbert (1988) isolated L. monocytogenes serotypes 1/2, 3a, 3b, $3 \mathrm{c}, 4 \mathrm{~b}, 4 \mathrm{~d}$ and nontypable from $60 \%$ of raw chicken samples (66\% from fresh and $54 \%$ from frozen birds), a percentage higher than that observed in our study. Other Listeria spp., including L. welshimeri, L. seeligeri and L. innocua, were isolated from $28 \%$ of chickens by the authors.

Samples of chicken liver investigated in this work were not contaminated by $L$. monocytogenes, but $L$. innocua serotype 6 a and $L$. grayi were detected.

According to Engelbrecht et al. (1996), the pathogenesis of listeriosis involves sequential expression of internalin A and B genes that induce phagocytosis of the bacteria by intestinal epithelial and liver cells, respectively. So livers could be an important source of pathogenic L. monocytogenes to humans. Also, patients with listeriosis showed high antibody levels against internalin from Listeria.

Although the occurrence of foodborne listeriosis has not been recognized in Brazil, it has widely been recognized in other countries in association with ingestion of various L. monocytogenes-contaminated foods, e.g., seafood, vegetables, dairy products, meat and poultry products (Farber and Peterkin 1991; Ericsson et al. 1997; Brett et al. 1998; Goulet et al. 1998). In most cases, where quantitative determinations were performed, causative foods were contaminated with levels as high as $\geq 10^{3} \mathrm{CFU} / \mathrm{g}$ (Farber and Peterkin 1991; Ericsson et al. 1997; Goulet et al. 1998). Based on epidemiological investigations and food surveys for $L$. monocytogenes contamination, levels lower than $100 \mathrm{~L}$ monocytogenes per $\mathrm{g}$ food have been assumed as safe (ICMSF 1994). 
Listeria monocytogenes can be recovered from the working environment where meat, contaminated with the organism, is processed. Thus, cross-contamination of cooked meat, raw vegetables and salads with $L$. monocytogenes from raw chicken handled in the kitchen or in another food-processing environment is a possibility.

\section{Prevalence and Most Probable Number of Listeria spp. on Saws and Tables}

In this study, Listeria spp. were isolated in 50\% of samples of the surface of mechanic saws (Table 1). Listeria monocytogenes serotypes $1 / 2 \mathrm{a}, 1 / 2 \mathrm{~b}, 4 \mathrm{~b}$ and $1 / 2 \mathrm{c}$, and L. innocua serotype 6 a were isolated in three of the five $(60 \%)$ samples contaminated. Listeria grayi were detected in all samples contaminated. Eight samples (80\%) of the surface of the cutting table were contaminated with $L$. monocytogenes (Table 1 ). High levels of $L$. monocytogenes were present on these surfaces, e.g., for saws $<30-2400$ MPN/equipment $(<0.005-$ $\left.0.4 \mathrm{MPN} / \mathrm{cm}^{2}\right)$ and for table, $<30-11,000 \mathrm{MPN} /$ equipment $(<0.0005-$ $0.183 \mathrm{MPN} / \mathrm{cm}^{2}$ ) (Table 2).

Autio et al. (2000) also investigated 73 environment samples from 10 abattoirs and isolated L. monocytogenes from 2 samples from a saw and 1 sample from a drain, a door and a table in the cutting room. According to the authors, the carcass samples were contaminated with L. monocytogenes in two abattoirs where the mechanical saws were used to cut the breasts. In this present study, L. monocytogenes was isolated from saws and tables at a higher frequency than that reported by Autio et al. (2000).

The presence in high numbers of Listeria spp. and L. monocytogenes in table and saws indicated that the disinfection procedures used at the poultry processing plant investigated in this study were ineffective.

According to Ryser and Marth (1999), industries in various countries that investigate the presence of Listeria and other pathogenic microorganisms in their processing plants and final products do not pass on the information to the scientific community. The authors considered that this is probably attributed to fear of negative publicity and risk of financial loss. Therefore, the amount of data published on the incidence of Listeria at industrial installations is small.

\section{Prevalence and Most Probable Number of Listeria spp. on Bare Hands and Hands with Gloves of Food Handlers}

In the samples of the bare hands of food handlers 6 of the $10(60 \%)$ samples presented Listeria, of which $2(33.33 \%)$ harbored L. monocytogenes serotype $4 \mathrm{~b}$. Listeria innocua $6 \mathrm{a}, 6 \mathrm{~b}$ and nontypable and L. grayi were isolated too. On hands with gloves only L. innocua and L. grayi were 


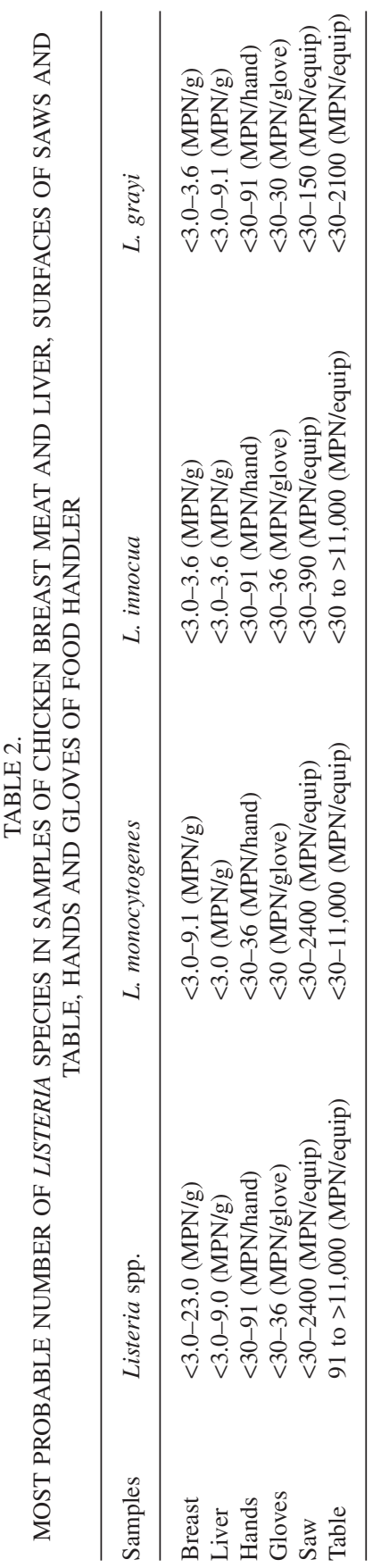


isolated. The levels of Listeria on hands and gloves were low ( $<110 \mathrm{MPN} /$ hand) (Table 2).

Genigeorgis et al. (1989) also analyzed swabs from gloves and the workers' hands, and found that up to 59\% of the people who worked at the end of the production line were carriers of Listeria. In the 1990, Genigeorgis et al. (1990) carried out a study at a turkey processing plant and found that samples of hands and gloves of food handlers, who hang up the carcasses after the chilling, cutting the carcasses and packaging, were contaminated by Listeria spp. at a frequency of $16.7 \%, 33.3 \%$ and $40.0 \%$, respectively. Kerr et al. (1993) investigated 99 workers' hands at 44 establishments and found that 12 (12\%) food workers carried Listeria spp. and 7 (7\%) carried L. monocytogenes. Our results indicate that the prevalence of Listeria spp. on the hands is very similar to that presented by Genigeorgis et al. (1989). However, the results concerning the prevalence of Listeria spp. and L. monocytogenes on these surfaces were higher than that reported by Kerr et al. (1993).

The chicken breast meat is usually eaten after being cooked, and therefore this food may be of low risk. However, the opportunities of crosscontamination with other foodstuffs in the consumer's kitchen should be considered, so the food industry should not ignore Good Manufacturing Practices (GMP) standards. Additionally an effective and properly applied sanitation program should be strictly followed to prevent $L$. monocytogenes contamination.

\section{ACKNOWLEDGMENTS}

We are grateful to Dr. Cristhiane Moura Falavina dos Reis and Ernesto Hofer (Brazil) for assistance in performing the serological analysis of Listeria species. This study was supported by CAPES, Brazil.

\section{REFERENCES}

ASSOCIATION OF OFFICIAL ANALYTICAL CHEMISTS. 1996. Official Methods of Analysis of AOA International, 16th Ed., Vol 2, AOAC, Gaithersburg.

AUTIO, T., HIELM, S., MIETTINEN, M., SJÖBERG, A.-M., AARNISAL, K., BJÖRKROTH, J., MANTTILA-SANDHOLM, T. and KORKEALA, H. 1999. Sources of Listeria monocytogenes contamination in a coldsmoked rainbow trout processing plant detected by pulsed-field gel electrophoresis. Appl. Environ. Microbiol. 65, 150-155. 
AUTIO, T., SATERI, T., FREDRIKSSON-AHOMAA, M., RAHKIO, M., LUNDEN, J. and KORKEALA, H. 2000. Listeria monocytogenes contamination pattern in pig slaughterhouses. J. Food Prot. 63, 1438-1442.

BRETT, M.S.Y., SHORT, P. and MCLAUCHLIN, J. 1998. A small outbreak of listeriosis associated with smoked mussels. Int. J. Food Microbiol. 43, 223-229.

DALEY, E.F., PAGOTTO, F. and FARBER, J.M. 1995. The inhibitory properties of various sponges on Listeria spp. Lett. Appl. Microbiol. 20, 195198.

DONNELLY, C.W., BRACKET, R.E., DOORES, S., LEE, W.H. and LOVETT, J. 1992. Listeria. In Compendium of Methods for the Microbiological Examination of Foods, 3rd Ed. (C. Vanderzant and D.F. Splittstoesser, eds.) pp. 637-663. American Public Health Association, Washington, DC.

DOROZYNSKI, A. 2000. Seven die in French Listeria outbreak. Br. Med. J. $320,601$.

ENGELBRECHT, S., THUM, S.K., OCHS, C., HASS, J., LOTTSPEICH, F., GOEBEL, W. and SOKOLOVIC, Z. 1996. A new PrfA - regulated gene of Listeria monocytogenes encoding a small secreted protein with belong to the family of internalin. Mol. Microbiol. 21, 823-837.

ERICSSON, H., EKLÖW, A., DANIELSSON-THAM, M.-L., LONCAREVIC, S., MENTZING, L.-O., PERSSON, I., UNNERSTAD, H. and THAM, W. 1997. An outbreak of listeriosis suspected to have been caused by rainbow trout. J. Clin. Microbiol. 35, 2904-2907.

FARBER, J.M. and PETERKIN, P.I. 1991. L. monocytogenes, a food-borne pathogen. Microbiol. Rev. 55, 476-501.

FONNESBECH VOGEL, B., HUSS, H.H., OJENIYI, B., AHRENS, P. and GRAM, L. 2001a. Elucidation of Listeria monocytogenes contamination routes in cold-smoked salmon processing plants detected by DNA-based typing methods. Appl. Environ. Microbiol. 67, 2586-2595.

FONNESBECH VOGEL, B., JORGENSEN, L.V., OJENIYI, B., HUSS, H.H. and GRAM, L. 2001b. Diversity of Listeria monocytogenes isolates from cold-smoked salmon produced in different smokehouses as assessed by random amplified polymorphic DNA analyses. Int. J. Food Microbiol. 65, 83-92.

FRANCO, C.M., QUINTO, E.J., FENTE, C., RODRIGUEZ-OTERO, J.L., DOMINGUEZ, L. and CEPEDA, A. 1995. Determination of the principal sources of Listeria spp. Contamination in poultry meat and a poultry processing plant. J. Food Prot. 58, 1320-1325.

GENIGEORGIS, C.A., DUTULESCU, D. and GARAYZABAL, J.F. 1989. Prevalence of Listeria spp. in poultry meat at the supermarket and slaughterhouse level. J. Food Prot. 52, 618-624. 
GENIGEORGIS, C.A., OANCA, P. and DUTULESCU, D. 1990. Prevalence of Listeria spp. in turkey meat at the supermarket and slaughterhouse level. J. Food Prot. 53, 282-288.

GIOVANNACCI, I., RAGIMBEAU, C., QUENGUINER, S., SALVAT, G., VENDEUVRE, J.-L., CARLIER, V. and ERMEL, G. 1999. Listeria monocytogenes in pork slaughtering and cutting plants. Use of RAPD, PFGE and PCR-REA for tracing and molecular epidemiology. Int. J. Food Microbiol. 53, 127-140.

GOULET, V., ROCOURT, J., REBIERE, I., JACQUET, C., MOYSES, C., DEHAUMONT, P., SALVAT, G. and VEIT, P. 1998. Listeriosis outbreak associated with the consumption of rillettes in France in 1993. J. Infect. Dis. 177, 155-160.

ICMSF. 1994. Choice of sampling plan and criteria for Listeria monocytogenes. Int. J. Food Microbiol. 22, 89-96.

INOUE, S., NAKAMA, A., ARAI, Y., KOBUBO, Y., MARUYAMA, T., SAITO, A., YOSHIDA, T., TERAO, M., YAMAMOTO, S. and KUMAGAI, S. 2000. Prevalence and contamination levels of Listeria monocytogenes in retail foods in Japan. Int. J. Food Microbiol. 59, 73-77.

KERR, K.G., BIRKENHEAD, D., SEALE, K., MAJOR, J. and HAWKEY, P.M. 1993. Prevalence of Listeria spp. on the hands of food workers. J. Food Prot. 56, 525-527.

LAWRENCE, L.M. and GILMOUR, A. 1994. Incidence of Listeria spp. and Listeria monocytogenes in a poultry processing environment and in poultry products and their rapid confirmation by PCR. Appl. Environ. Microbiol. 60, 4600-4604.

LAWRENCE, L.M. and GILMOUR, A. 1995. Characterization of Listeria monocytogenes isolated from poultry and from the poultry-processing environment by random amplification of polymorphic DNA and multilocus enzyme electrophoresis. Appl. Environ. Microbiol. 61, 21392144.

MESSER, J.W., MIDURA, T.F. and PEELER, J.T. 1992. Sampling plans, sample collection, shipment, and preparation for analysis. In Compendium of Methods for Microbiological Examination of Foods, 3rd Ed. (C. Vanderzant and D.F. Splittstoesser, eds.) pp. 25-49. American Public Health Association, Washington, DC.

MIETTINEN, M.K., PALMU, L., BJORKROTH, K.J. and KORKEALA, H. 2001. Prevalence of Listeria monocytogenes in broilers at the abattoir, processing plant, and retail level. J. Food Prot. 64, 994-999.

PINI, P.N. and GILBERT, R.J. 1988. The occurrence in the U.K. of Listeria species in raw chickens and soft cheeses. Int. J. Food Microbiol. 6, 317326. 
RORVIK, L.M., AASE, B., ALVESTAD, T. and CAUGANT, D. 2000. Molecular epidemiology survey of Listeria monocytogenes and seafoodprocessing plants. Appl. Environ. Microbiol. 66, 4779-478.

RYSER, E.T. and MARTH, E.H. 1999. Listeria, Listeriosis and Food Safety, 2nd Ed., p. 738, Marcel Dekker, New York.

SALVAT, G., TOQUIN, M.T., MICHEL, Y. and COLIN, P. 1995. Control of Listeria monocytogenes in the delicatessen industries: The lessons of a listeriosis outbreak in France. Int. Food Microbiol., 84, 255-261.

SEELIGER, H.P.R. and HOHNE, K. 1979. Serotyping of Listeria monocytogenes and related species. In Methods in Microbiology ( $\mathrm{T}$. Bergan and J.R. Morris, eds.) pp. 31-49. Academic Press, New York.

UYTTENDAELE, M., DE TROY, P. and DEBEVERE, J. 1999. Incidence of Listeria monocytogenes in different types of meat products on the Belgian retail market. Int. J. Food Microbiol. 53, 75-80. 